\title{
THE EFFECT OF CALCINATION TEMPERATURE ON COBALT OXIDE SPECIES AND PERFORMANCE FOR CATALYTIC OZONATION OF $\mathrm{NH}_{4}^{+}$IN WATER
}

\section{Pengaruh Suhu Kalsinasi pada Cobalt Oksida dan Kinerjanya untuk Ozonasi Katalitik $\mathrm{NH}_{4}{ }^{+}$dalam Air}

\author{
Lina Mahardiani * \\ Department of Chemistry Education, Faculty of Teacher Training and Education \\ Universitas Sebelas Maret \\ Ir. Sutami Street No. 36 A, Surakarta, Central Java, 57126, Indonesia \\ * Correspondence : e-mail: mahardiani.lina@staff.uns.ac.id
}

Received: January 09, 2019

DOI : 10.20961/jkpk.v4i3.26702
Accepted: December 30, 2019

Online Published: December 31, 2019

\begin{abstract}
Cobalt oxide catalysts can be prepared by impregnation and calcined under different temperatures to obtained different species of cobalt oxide, namely $\mathrm{CoO}(\mathrm{OH}), \mathrm{Co}_{3} \mathrm{O}_{4}$, and $\mathrm{CoO}$. $\mathrm{Co}_{3} \mathrm{O}_{4}$ was the most appropriate catalyst for decomposing $\mathrm{NH}_{4}{ }^{+}$with $\mathrm{O}_{3}$ in the presence of $\mathrm{Cl}^{-}$ because of relatively high activity, $74 \%$, and high selectivity for gas products, $88 \%$, compared to $\mathrm{CoO}$ and $\mathrm{CoO}(\mathrm{OH}) . \mathrm{Cl}^{-}$is necessary to proceed with the catalytic ozonation of $\mathrm{NH}_{4}^{+}$since $\mathrm{Cl}^{-}$ participate in the catalytic ozonation mechanism, while $\mathrm{SO}_{4}{ }^{2-}$ inhibited the process. During the catalytic ozonation of $\mathrm{NH}_{4}{ }^{+}, \mathrm{Co}_{3} \mathrm{O}_{4}$ showed no deactivation rather than enhanced the catalytic performance after repeated used up to $100 \%$ of $\mathrm{NH}_{4}{ }^{+}$conversion. The $\mathrm{Co}_{3} \mathrm{O}_{4}$ can be regenerated by recalcining the catalyst under air at high temperatures.
\end{abstract}

Keywords: Cobalt oxide species, $\mathrm{Co}_{3} \mathrm{O}_{4}$, catalytic ozonation $\mathrm{NH}_{4}^{+}$, stability, regeneration

\section{ABSTRAK}

Katalis oksida kobalt dapat dibuat dengan cara impregnasi dan kalsinasi pada suhu yang berbeda untuk memperoleh berbagai spesies oksida kobalt, yaitu $\mathrm{CoO}(\mathrm{OH}), \mathrm{Co}_{3} \mathrm{O}_{4}$, dan $\mathrm{CoO}$. $\mathrm{Co}_{3} \mathrm{O}_{4}$ merupakan katalis yang paling tepat untuk mendekomposisi $\mathrm{NH}_{4}{ }^{+}$dengan $\mathrm{O}_{3}$ dengan adanya $\mathrm{Cl}^{-}$karena aktivitasnya yang relatif tinggi, 74\%, dan selektivitas yang tinggi untuk produk gas, $88 \%$, dibandingkan dengan $\mathrm{CoO}$ dan $\mathrm{CoO}(\mathrm{OH})$. $\mathrm{Cl}^{-}$diperlukan untuk memproses ozonasi katalitik $\mathrm{NH}_{4}{ }^{+}$karena $\mathrm{Cl}^{-}$berpartisipasi dalam mekanisme ozonasi katalitik, sedangkan $\mathrm{SO}_{4}{ }^{2-}$ menghambat proses. Selama ozonasi katalitik $\mathrm{NH}_{4}{ }^{+}, \mathrm{Co}_{3} \mathrm{O}_{4}$ tidak menunjukkan deaktivasi melainkan peningkatan performa katalitik setelah penggunaan berulang untuk konversi $\mathrm{NH}_{4}{ }^{+}$ hingga 100\%. Co3O4 dapat diregenerasi dengan rekalsinasi katalis pada suhu udara tinggi.

Kata Kunci: Spesies oksida kobalt, $\mathrm{Co}_{3} \mathrm{O}_{4}$, ozonasi katalitik $\mathrm{NH}_{4}{ }^{+}$, stabilitas, regenerasi

\section{INTRODUCTION}

Water is the most widespread substance to be found in the natural environment and it plays vital roles in both environment and human lives. Since more than $97 \%$ water on the earth is sea water, fresh water is only $3 \%$. About $0.3 \%$ of fresh water is held in 
rivers, lakes, and reservoirs, while the rest is stored in glaciers, permanent snow and groundwater aquifers [1].

One of the pollutants generated from disposal of industrial wastewater, household sewage discharge, excess fertilization and inappropriate disposal of livestock excreta is ammonia $\left(\mathrm{NH}_{3}\right)$ and ammonium ion $\left(\mathrm{NH}_{4}{ }^{+}\right)$. Hereafter those are called ammonia nitrogen. Ammonia nitrogen can cause eutrophication and is toxic to fish and aquatic organisms [2, 3] in addition to the offensive smell and potential carcinogenesis [4]. Furthermore, growth of algae and bacteria population in drinking water will rise caused by ammonia nitrogen [5], it should be removed to prevent environmental damage.

Catalytic ozonation is one of advance oxidation process which is proven effective for treating refractory pollutants [6-8]. Catalytic ozonation gained a lot of attention due to its advantages, such as mild reaction conditions (ordinary temperature and pressure) and high effectiveness for organic pollutants degradation. In catalytic ozonation, even though ozone is one of strong oxidizer, it is not enough for total mineralization of the contaminant in the absence of catalyst [8-10]. Heterogeneous catalyst that usually applied for catalytic ozonation is metal oxide and cobalt oxide is one of them [9, 11-13].

Cobalt oxide has great potential for catalysis $[12,14,15]$, electrochemistry $[16$, 17], sensing devices [18] and magnetic materials [19] to name a few. There are several cobalt oxides that showed significant performance to their potential, namely $\mathrm{CoO}$, $\mathrm{CoO}_{2}, \mathrm{Co}_{2} \mathrm{O}_{3}, \mathrm{CoO}(\mathrm{OH})$ and $\mathrm{Co}_{3} \mathrm{O}_{4}$. However, mostly $\mathrm{Co}_{3} \mathrm{O}_{4}$ and $\mathrm{CoO}$ are used due to their stability $[18,20]$. These cobalt oxides were synthesized using various methods such as hydrothermal [21], precipitation [22-24], impregnation [13], femtosecond laser ablation [16], solid-state [14] and core-shell [15].

In the previous study of catalytic ozonation of $\mathrm{NH}_{4}^{+}$, Ichikawa et al [13] have reported that $\mathrm{Co}_{3} \mathrm{O}_{4}$ showed moderate performance with high selectivity of gaseous gas than $\mathrm{NO}_{3}{ }^{-}$as product. In the contrary, Liu [14] showed that $\mathrm{Co}_{3} \mathrm{O}_{4}$ and $\mathrm{Co}_{3} \mathrm{O}_{4}$-enhanced with surfactant had low activity and selectivity toward nitrogen gas when treating $\mathrm{NH}_{4}{ }^{+}$in water. In this study, the facile synthesis of cobalt oxide was conducted based on the calcination temperature only to form different cobalt oxide catalysts. The purpose of this study was to apply the catalytic ozonation for ammonia decomposition in water in the presence of cobalt oxides. In addition, the stability of $\mathrm{Co}_{3} \mathrm{O}_{4}$ as heterogeneous catalyst was also have been investigated by repeated use.

\section{EXPERIMENTAL}

\section{Synthesis of catalysts}

The cobalt oxide catalysts were prepared by a precipitation method following the procedure used by Ichikawa et al [13]. Cobalt nitrate, $\mathrm{Co}\left(\mathrm{NO}_{3}\right)_{2} .6 \mathrm{H}_{2} \mathrm{O}$, as source of cobalt was mixed with aqueous ammonia until the $\mathrm{pH}$ reached 8 . The found precipitate was then filtered, washed with distilled water and dried at $100^{\circ} \mathrm{C}$ for two days, followed by calcination at $450^{\circ} \mathrm{C}$ for $3 \mathrm{~h}$ to obtain $\mathrm{Co}_{3} \mathrm{O}_{4}$. As for the $\mathrm{CoO}(\mathrm{OH})$ and $\mathrm{CoO}$ formation were conducted by calcined $\mathrm{Co}_{3} \mathrm{O}_{4}$ under $\mathrm{N}_{2}$ gas for $4 \mathrm{~h}$ with different temperatures, namely 260 and $850^{\circ} \mathrm{C}$, respectively. 


\section{Catalytic ozonation of $\mathrm{NH}_{4}{ }^{+}$}

The catalytic ozonation of $\mathrm{NH}_{4}{ }^{+}$was carried out in a batch reactor. The reaction solution containing $\mathrm{NH}_{4} \mathrm{Cl}(10 \mathrm{mmol} / \mathrm{L})$ and catalyst was heated up to $60^{\circ} \mathrm{C}$ with stirring. After temperature reached to $60^{\circ} \mathrm{C}, \mathrm{O}_{3} / \mathrm{O}_{2}$ mixture was introduced into the reactor to start the reaction. The catalytic ozonation of $\mathrm{NH}_{4}{ }^{+}$was also conducted using $\left(\mathrm{NH}_{4}\right)_{2} \mathrm{SO}_{4}$ and $\left(\mathrm{NH}_{4}\right)_{2} \mathrm{CO}_{3}$ under same reaction condition. The aqueous phase was analyzed using ion chromatographs to determine the concentrations of $\mathrm{NH}_{4}{ }^{+}$and $\mathrm{NO}_{3}{ }^{-}$. $\mathrm{NO}_{2}{ }^{-}$was not formed at all under the reaction conditions.

\section{Repeated use of $\mathrm{Co}_{3} \mathrm{O}_{4}$ for catalytic ozonation of $\mathrm{NH}_{4}{ }^{+}$}

Catalytic ozonation of $\mathrm{NH}_{4}^{+}$in water $\left(\mathrm{NH}_{4} \mathrm{Cl}, 10 \mathrm{mmol} \mathrm{L} \mathrm{L}^{-1}\right)$ was carried out in a batch reactor at $60^{\circ} \mathrm{C}$ with vigorous stirring in a stream of $\mathrm{O}_{2} / \mathrm{O}_{3}$. Concentration of $\mathrm{NH}_{4}{ }^{+}$and $\mathrm{NO}_{3}{ }^{-}$were determined by using ion chromatographs. After the reaction, the catalyst was separated by filtration, washed with distilled water and dried overnight at $100^{\circ} \mathrm{C}$. The spent catalyst was then reused for the catalytic ozonation of $\mathrm{NH}_{4}{ }^{+}$under the reaction conditions similar to those for the first run. The reactions were repeated for several times.

\section{RESULTS AND DISCUSSION}

Preparation of cobalt oxide plays important role to determine the cobalt oxide $\left(\mathrm{CoO}_{x}\right)$ species. Among the parameters, catalyst precursor and calcination temperature are considered to be crucial $[20,25]$. The calcination of $\mathrm{Co}\left(\mathrm{NO}_{3}\right)_{2}$ at $300-800^{\circ} \mathrm{C}$ leads to its decomposition to $\mathrm{Co}_{3} \mathrm{O}_{4}$, as shown in Eq.1
$3 \mathrm{Co}\left(\mathrm{NO}_{3}\right)_{2}\left(\mathrm{H}_{2} \mathrm{O}\right)_{6} \rightarrow \mathrm{Co}_{3} \mathrm{O}_{4}+6 \mathrm{NO}_{2}+\mathrm{O}_{2}+18 \mathrm{H}_{2} \mathrm{O}(1)$

Meanwhile, $\mathrm{Co}_{3} \mathrm{O}_{4}$ can also be obtained from oxidation and decomposition of $\mathrm{Co}(\mathrm{OH})_{2}$, as represented in Eq. 2-4 [25, 26].

$$
\begin{aligned}
& \mathrm{Co}(\mathrm{OH})_{2} \mathrm{NO}_{3}+\mathrm{KOH} \rightarrow \mathrm{Co}(\mathrm{OH})_{2}+\mathrm{KNO}_{3} \\
& 4 \mathrm{Co}(\mathrm{OH})_{2}+\mathrm{O}_{2}+\mathrm{H}_{2} \mathrm{O} \rightarrow 4 \mathrm{Co}(\mathrm{OH})_{3} \\
& 6 \mathrm{Co}(\mathrm{OH})_{3} \rightarrow 2 \mathrm{Co}_{3} \mathrm{O}_{4}+9 \mathrm{H}_{2} \mathrm{O}+1 / 2 \mathrm{O}_{2}
\end{aligned}
$$

In addition, heating $\mathrm{Co}_{3} \mathrm{O}_{4}$ under inert gas like $\mathrm{N}_{2}$ at temperature above $850^{\circ} \mathrm{C}$ will resulted the formation of $\mathrm{CoO}[20,27,28]$ and $\mathrm{CoO}(\mathrm{OH})$ when $\mathrm{CoO} x$ was thermally decomposed under $270^{\circ} \mathrm{C}[20,21,23]$. The cobalt oxides collected for this study agrees with the theories mentioned. The cobalt nitrate calcined at 450 and $650^{\circ} \mathrm{C}$ are $\mathrm{Co}_{3} \mathrm{O}_{4}$ species and $\mathrm{Co}_{3} \mathrm{O}_{4}$ which was further calcined at 260 and $850^{\circ} \mathrm{C}$ are $\mathrm{CoO}(\mathrm{OH})$ and $\mathrm{CoO}$, respectively. Next, those cobalt oxide species were utilized for catalytic ozonation of $\mathrm{NH}_{4}+$ in water.

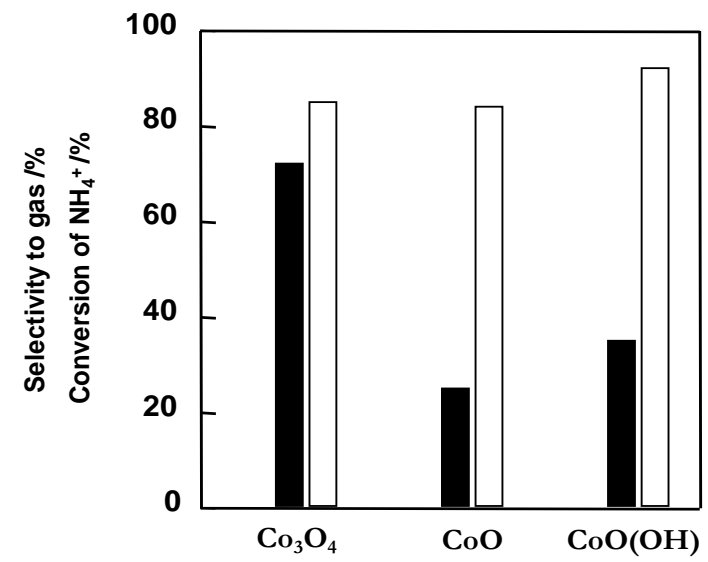

Fig 1. The performance of cobalt oxide catalyst for catalytic ozonation of $\mathrm{NH}_{4}{ }^{+}$. $(\square)$ conversion of $\mathrm{NH}_{4}{ }^{+}$and $(\square)$ selectivity to gaseous product. Reaction parameter: $\mathrm{NH}_{4} \mathrm{Cl}, 10 \mathrm{mmol} \mathrm{L}^{-1} ; \mathrm{O}_{3} / \mathrm{O}_{2}$ total flow rate, $100 \mathrm{~cm}^{3} \mathrm{~min}^{-1} ; \mathrm{T}, 60^{\circ} \mathrm{C}$; $\mathrm{t}, 6 \mathrm{~h}$; catalyst, $0.10 \mathrm{~g}$. 
Figure 1. exhibits the performance of $\mathrm{Co}_{3} \mathrm{O}_{4}, \mathrm{CoO}$ and $\mathrm{CoO}(\mathrm{OH})$ based on the conversion of $\mathrm{NH}_{4}{ }^{+}$and selectivity to gaseous product. The activities of those three cobalt oxide species were different. $\mathrm{Co}_{3} \mathrm{O}_{4}$ showed highest conversion of $\mathrm{NH}_{4}^{+}$at $74 \%$ and followed by $\mathrm{CoO}(\mathrm{OH})$ and $\mathrm{CoO}$ about 36 and $23 \%$, respectively. $\mathrm{Co}_{3} \mathrm{O}_{4}$ is consist of $\mathrm{Co}^{2+}$, $\mathrm{Co}^{3+}$ and $\mathrm{O}_{4}{ }^{2-}$. The activity of $\mathrm{Co}_{3} \mathrm{O}_{4}$ is high likely because well-dispersed $\mathrm{Co}^{2+}$ species acted as active sites. It is also expected that redistribution of $\mathrm{Co}^{2+}$ and $\mathrm{Co}^{3+}$ in cobalt happened during ozonation [28]. Meanwhile, all three cobalt oxide species show similar trend in selectivity to gaseous product about $85-90 \%$ of $\mathrm{NH}_{4}{ }^{+}$. High selectivity was occurred because the surface density of $\mathrm{NH}_{x}$ adsorbed is expected to be high compared to $\mathrm{O}^{*}$ adsorbed on the surface of $\mathrm{Co}_{3} \mathrm{O}_{4}$ [13]. Therefore, it can be said that $\mathrm{Co}_{3} \mathrm{O}_{4}$ posses more active sites compared to $\mathrm{CoO}$ and $\mathrm{CoO}(\mathrm{OH})$.

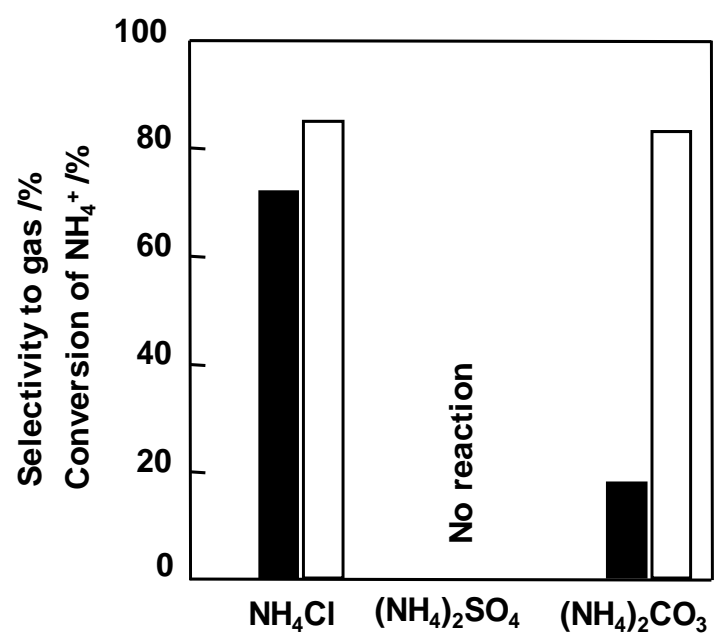

Fig 2. The performance of $\mathrm{Co}_{3} \mathrm{O}_{4}$ catalyst for catalytic ozonation of $\mathrm{NH}_{4}{ }^{+}$from different

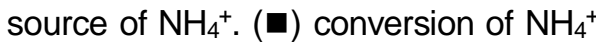
and $(\square)$ selectivity to gaseous product. Reaction parameter: $\mathrm{NH}_{4}^{+}, 10 \mathrm{mmol} \mathrm{L}^{-1}$; $\mathrm{O}_{3} / \mathrm{O}_{2}$ total flow rate, $100 \mathrm{~cm}^{3} \mathrm{~min}^{-1} ; \mathrm{T}$, $60^{\circ} \mathrm{C} ; \mathrm{t}, 6 \mathrm{~h} ; \mathrm{Co}_{3} \mathrm{O}_{4}, 0.10 \mathrm{~g}$.
The catalytic ozonation of $\mathrm{NH}_{4}{ }^{+}$over $\mathrm{Co}_{3} \mathrm{O}_{4}$ was also performed using different source of $\mathrm{NH}_{4}^{+}$, namely $\left(\mathrm{NH}_{4}\right)_{2} \mathrm{SO}_{4}$ and $\left(\mathrm{NH}_{4}\right)_{2} \mathrm{CO}_{3}$. In the absence of $\mathrm{Cl}^{-}$, the conversion of $\mathrm{NH}_{4}{ }^{+}$was low when $\left(\mathrm{NH}_{4}\right)_{2} \mathrm{CO}_{3}$ was used and no catalytic ozonation of $\mathrm{NH}_{4}{ }^{+}$ occurred when $\left(\mathrm{NH}_{4}\right)_{2} \mathrm{SO}_{4}$ applied, as shown in Figure 2. Thus, to clarify the role of $\mathrm{Cl}^{-}$on catalytic ozonation of $\mathrm{NH}_{4}{ }^{+}$over $\mathrm{Co}_{3} \mathrm{O}_{4}$, once again $\left(\mathrm{NH}_{4}\right)_{2} \mathrm{SO}_{4}$ solution was used as the source of $\mathrm{NH}_{4}^{+}$but this time $\mathrm{Cl}^{-}$was added into the reaction solution. This graph shows the relationship between $\mathrm{Cl}^{-}$concentration with the catalytic performance of $\mathrm{Co}_{3} \mathrm{O}_{4}$. As shown here, the higher the concentration of $\mathrm{Cl}^{-}$ , the higher the conversion of $\mathrm{NH}_{4}{ }^{+}$and so was the selectivity to gaseous product (Figure 3 ).

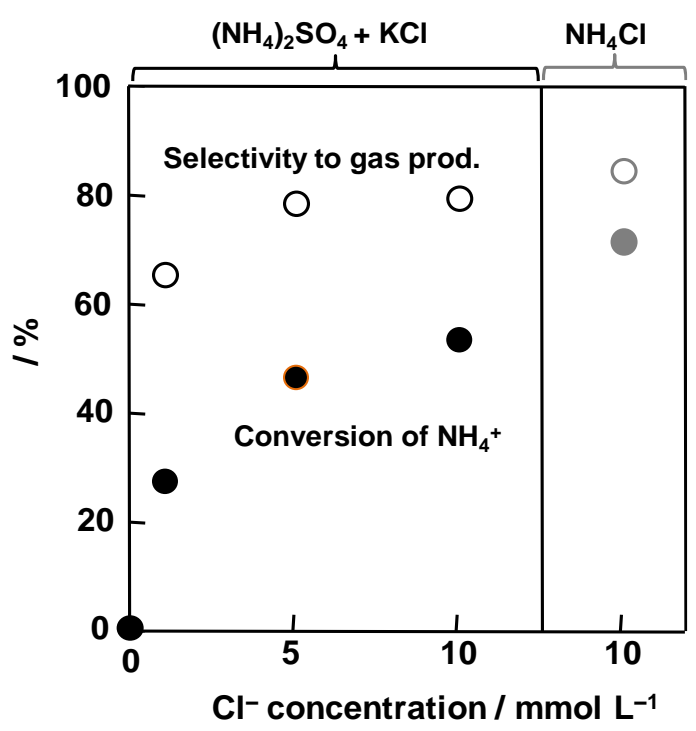

Fig 3. The performance of $\mathrm{Co}_{3} \mathrm{O}_{4}$ catalyst for catalytic ozonation of $\mathrm{NH}_{4}{ }^{+}$in the presence of $\mathrm{KCl}$. (O) conversion of $\mathrm{NH}_{4}{ }^{+}$and $(\mathrm{O})$ selectivity to gaseous product. Reaction parameter: $\mathrm{NH}_{4}^{+}, 10 \mathrm{mmol} \mathrm{L}{ }^{-1} ; \mathrm{O}_{3} / \mathrm{O}_{2}$ total flow rate, $100 \mathrm{~cm}^{3} \mathrm{~min}^{-1} ; \mathrm{T}, 60^{\circ} \mathrm{C}$; t, $6 \mathrm{~h} ; \mathrm{CO}_{3} \mathrm{O}_{4}, 0.10 \mathrm{~g}$.

The results demonstrate that $\mathrm{Cl}^{-}$was participated in the catalytic ozonation cycle over $\mathrm{Co}_{3} \mathrm{O}_{4}$ [13]. However, if we compared 
the results from $\left(\mathrm{NH}_{4}\right)_{2} \mathrm{SO}_{4}$ as $\mathrm{NH}_{4}{ }^{+}$source with $\mathrm{NH}_{4} \mathrm{Cl}$, we can see that the catalytic performance of $\mathrm{Co}_{3} \mathrm{O}_{4}$ was a little lower for $\left(\mathrm{NH}_{4}\right)_{2} \mathrm{SO}_{4}$, which suggests that $\mathrm{SO}_{4}{ }^{2-}$ inhibited the reaction.

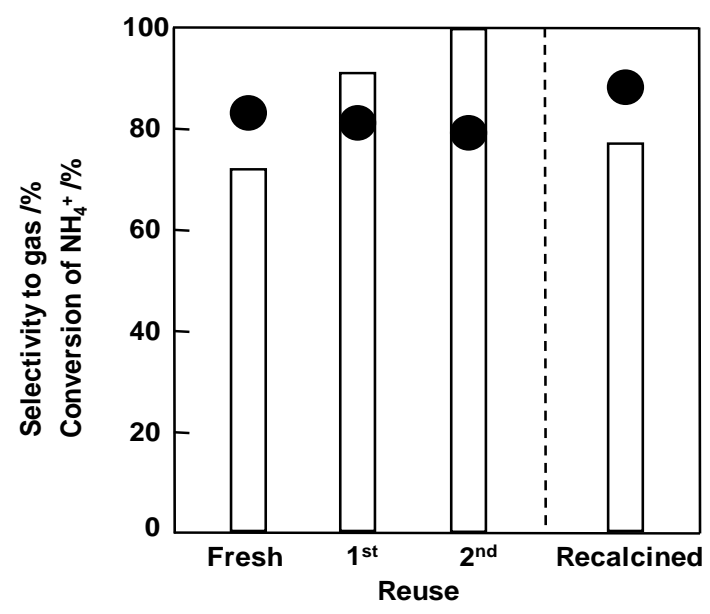

Fig 4. The performance of $\mathrm{CO}_{3} \mathrm{O}_{4}$ catalyst for catalytic ozonation of $\mathrm{NH}_{4}{ }^{+}$with repeated used and recalcination. ( $\square$ ) conversion of $\mathrm{NH}_{4}{ }^{+}$and $(\mathbf{O})$ selectivity to gaseous product. Reaction parameter: $\mathrm{NH}_{4}^{+}, 10$ $\mathrm{mmol} \mathrm{L}-1 ; \mathrm{O}_{3} / \mathrm{O}_{2}$ total flow rate, $100 \mathrm{~cm}^{3}$ $\min ^{-1} ; \mathrm{T}, 60^{\circ} \mathrm{C} ; \mathrm{t}, 6 \mathrm{~h} ; \mathrm{Co}_{3} \mathrm{O}_{4}, 0.10 \mathrm{~g}$. Recalcination: $\mathrm{T}, 450^{\circ} \mathrm{C}$ and $\mathrm{t}, 3 \mathrm{~h}$.

In the previous study [29] reported that conversion of $\mathrm{NH}_{4}+$ was $100 \%$ after repeated used of $\mathrm{Co}_{3} \mathrm{O}_{4}$ catalyst, due to the formation of $\mathrm{Co}-\mathrm{NH}_{x}$ functional group. This clearly showing that $\mathrm{Co}_{3} \mathrm{O}_{4}$ is an excellent catalyst since no deactivation happened. Deactivation of catalyst can be caused by sintering, fouling, poisoning or thermal degradation [30] and usually able to be generated for reuse in the same or related process [31]. In general, heterogeneous catalyst can be regenerated to regain the active site of the catalyst. $\mathrm{Co}_{3} \mathrm{O}_{4}$ was washed with distilled water and dried overnight before being used for the next same procedure. The spent $\mathrm{Co}_{3} \mathrm{O}_{4}$ undergone recalcination after being used for three times at $450^{\circ} \mathrm{C}$ for $3 \mathrm{~h}$ (Figure 4). The recalcination of $\mathrm{Co}_{3} \mathrm{O}_{4}$ showed slightly better activity compared to fresh $\mathrm{Co}_{3} \mathrm{O}_{4}$. This is possible because exposing catalyst to oxygen at high temperature will make metal redispersed through gas phase and oxidation may offer a route to removal of poison on catalyst [31]. Nevertheless, to understand the real reason on the effect of recalcination toward the catalyst activity, further investigation is needed.

\section{CONCLUSIONS}

$\mathrm{Co}_{3} \mathrm{O}_{4}$ was the most appropriate catalyst for decomposing $\mathrm{NH}_{4}{ }^{+}$with $\mathrm{O}_{3}$ in the presence of $\mathrm{Cl}^{-}$because of relatively high activity and high selectivity for gas products compared to $\mathrm{CoO}$ and $\mathrm{CoO}(\mathrm{OH})$, due to high dispersion of the $\mathrm{Co}^{2+}$ and $\mathrm{Co}^{3+}$ active sites. $\mathrm{Cl}^{-}$is necessary to proceed the catalytic ozonation of $\mathrm{NH}_{4}{ }^{+}$since $\mathrm{Cl}^{-}$participate in the catalytic ozonation mechanism, while $\mathrm{SO}_{4}{ }^{2-}$ inhibited the process. During the catalytic ozonation of $\mathrm{NH}_{4}^{+}, \mathrm{Co}_{3} \mathrm{O}_{4}$ showed no deactivation rather than enhanced the catalytic performance after repeated used up to $100 \%$ of $\mathrm{NH}_{4}{ }^{+}$conversion. The $\mathrm{Co}_{3} \mathrm{O}_{4}$ can be regenerated by recalcining the catalyst under air at high temperature.

\section{REFERENCES}

[1] D. Pimentel, B. Berger, D. Filiberto, M. Newton, B. Wolfe, E. Karabinakis, S. Clark, E. Poon, E. Abbett, \& S. Nandagopal, "Water Resources: Agricultural and Environmental Issues," Bioscience, vol. 54, no. 10, pp. 909-918, 2004.

[2] B. W. Mercer, L. L. Ames, C. J. Touhill, W. J. Van Slyke \& R. B. Dean, "Ammonia Removal from Secondary Effluents by Selective Ion Exchange," 
Water Pollut. Control Fed., vol.42, no. 2, pp. R95-R107, 1970.

[3] R. V. Thurston, R. C. Russo, \& G. A. Vinogradov, "Ammonia toxicity to fishes. Effect of $\mathrm{pH}$ on the toxicity of the un-ionized ammonia species," Environmental Science and Technology, vol. 15, no. 7, pp. 837-840, 198.

[4] K. W. Kim, Y. J. Kim, I. T. Kim, G. I. Park, \& E. H. Lee, "The electrolytic decomposition mechanism of ammonia to nitrogen at an IrO2 anode". Electrochim. Acta, vol. 50, pp. 4356-4364, 2005.

[5] M. Klare, J. Scheen, K. Vogelsang, H. Jacobs, \& J. A. C. Broekaert, "Degradation of short-chain alkyl- and alkanolamines by $\mathrm{TiO} 2$ - and $\mathrm{Pt} / \mathrm{TiO} 2$-assisted photocatalysis," Chemosphere, vol. 41, no. 3, pp. 353-362, 2000.

[6] B. Legube \& N. K. V. Leitner, "Catalytic ozonation: a promising advanced oxidation technology for water treatment," Catal. Today, vol. 53, no. 1, pp. 61-72, 1999.

[7] B. Kasprzyk-Hordern, M. Ziolek, \& J. Nawrocki, "Catalytic ozonation and methods of enhancing molecular ozone reactions in water treatment," Appl. Catal. B: Environ. vol. 46, no. 3, pp. 639-669, 2003.

[8] Y. Guo, L. Yang, X. Cheng, \& X. Wang, "The Application and Reaction Mechanism of Catalytic Ozonation in Water Treatment," J Environ Anal Toxicol, vol. 2, no. 7, pp. 150-155, 2012.

[9] P. C. C. Faria, D. C. M. Monteiro, J. J. M. Orfao, \& M. F. R. Pereira, "Cerium, manganese and cobalt oxides as catalysts for the ozonation of selected organic compounds," Chemosphere, vol. 74, no. 6, pp. 818-824, 2009.

[10] A. Ikhlaq, D. R. Brown, \& B. KasprzykHordern, "Mechanisms of catalytic ozonation on alumina and zeolites in water: Formation of hydroxyl radicals," Appl. Catal. B: Environ., vol. 123-124 pp. 94-106, 2012.
[11] P. M. Alvarez, F. J. Beltran, J. P. Pocostales, \& F. J. Mas, "Preparation and structural characterization of $\mathrm{Co} / \mathrm{Al} 2 \mathrm{O} 3$ catalysts for the ozonation of pyruvic acid," Appl. Catal. B: Environ., vol. 72, pp. 322-330, 2007.

[12] E. Wilczkowska, K. Krawczyk, J. Petryk, J. W. Sobczak, \& Z. Kaszkur, "Direct nitrous oxide decomposition with a cobalt oxide catalyst," Appl. Catal. A: Gen., vol. 389, pp. 165-172, 2010.

[13] S. Ichikawa, L. Mahardiani, \& Y. Kamiya, "Catalytic oxidation of ammonium ion in water with ozone over metal oxide catalysts," Catal. Today, vol. 232 , pp. 192-197, 2014.

[14] C. Liu, Y. Chen, L. Guo, \& C. Li, "Fabrication of Surfactant-Enhanced Metal Oxides Catalyst for Catalytic Ozonation Ammonia in Water," Int. J. Environ. Res. Publich Health, vol. 15, no. 8, pp. 1654-1668, 2018.

[15] S. Mo, Q. Zhang, Y. Sun, M. Zhang, J. Li, Q. Ren, M. Fu, J. Wu, L. Chen, \& D. $\mathrm{Ye}$, "Gaseous $\mathrm{CO}$ and toluene cooxidation over monolithic core-shell $\mathrm{Co}_{3} \mathrm{O}_{4}$ - based hetero- structured catalysts," J. Mater. Chem. A, vol. 7, no. 27, pp. 16197-16210, 2019.

[16] T. Nishi, Y. Hayasaka, T. M. Suzuki, S. Sato, N. Isomura, N. Takahashi, S. Kosaka, T. Nakamura, S. Sato, T. Morikawa, "Electrochemical Water Oxidation Catalysed by $\mathrm{CoO}-\mathrm{Co}_{2} \mathrm{O}_{3}-$ $\mathrm{Co}(\mathrm{OH})_{2}$ Multiphase- Nanoparticles Prepared by Femtosecond Laser Ablation in Water," ChemistrySelect, vol. 3, no. 17, pp. 4979-4984, 2018.

[17] F. Reikowski, F. Maroun, I. Pacheco, T. Wiegmann, P. Allongue, J. Stettner, O. M. Magnussen, "Operando Surface X-ray Diffraction Studies of Structurally Defined $\mathrm{Co}_{3} \mathrm{O}_{4}$ and $\mathrm{CoOOH}$ Thin Films during Oxygen Evolution," ACS Catal., vol. 9, no. 5, pp. 3811-3821, 2019.

[18] P. Hu \& M. Long, "Cobalt-catalyzed sulfate radical-based advanced oxidation: A review on heterogeneous catalysts and applications," Appl. 
Catal. B: Environ., vol. 181, pp. 103117, 2016.

[19] R. Ashraf, M. Bashir, M. A. Raza, S. Riaz, \& S. Naseem, "Effect of Calcination on Structural And Magnetic Properties of Co Doped Zno Nanostructur conference," Paper: Intermag 2015-IEEE International Magnetics Conference, 2015.

[20] C. W. Tang, C. B. Wang \& S. H. Chien, "Characterization of Cobalt Oxides Studied by FT-IR, Raman, TPR and TG-MS," Thermochimica Acta, vol. 473, pp. 68-73, 2008.

[21] J. Yang \& T. Sasaki, "Synthesis of $\mathrm{CoOOH}$ Hierarchically Hollow Spheres by Nanorod Self-Assembly through Bubble Templating," Chem. Mater. vol. 20, no. 5, pp. 2049-2056, 2008.

[22] H-K. Lin, H-C. Chiu, H-C. Tsai, S-H. Chien, C-B. Wang, "Synthesis, Characterization and Catalytic Oxidation of Carbon Monoxide over Cobalt Oxide," Catalysis Letter, vol. 88, pp. 169-174, 2003.

[23] J. Yang, H. Liu, W. N. Martens, \& R. L. Frost, "Synthesis and Characterization of Cobalt Hydroxide, Cobalt Oxyhydroxide, and Cobalt Oxide Nanodiscs," J. Phys. Chem. C, vol. 114, no. 1, pp. 111-119, 2010.

[24] X. Chen, J. P. Cheng, Q. L. Shou, F. Liu, X. B. Zhang, "Effect of calcination temperature on the porous structure of cobalt oxide micro-flowers," CrystEngComm., vol. 14, no. 4, pp. 1271-1276, 2012.
[25] S. L. Sharifi, H. R. Shakur, A. Mirzaei, A. Salmani, \& M. H. Hosseini, "Characterization of Cobalt Oxide $\mathrm{Co}_{3} \mathrm{O}_{4}$ Nanoparticles Prepared by Various Methods: Effect of Calcination Temperatures on Size, Dimension and Catalytic Decomposition of Hydrogen Peroxide," Int. J. Nanosci. Nanotechnol., vol. 9, no. 1, pp. 51-58, 2013.

[26] H. Becker, T. Turek, \& R. Guttel, "Study of temperature-programmed calcination of cobalt-based catalysts under NO-containing atmosphere," Catal. Today, vol. 215, pp. 8-12, 2013.

[27] Z. P. Xu \& H. C. Zeng, "Thermal evolution of cobalt hydroxides: a comparative study of their various structural phases," J. Mater. Chem. vol. 8, no. 11, pp. 2499-2506, 1998.

[28] M. Gruttadauria, L. F. Liotta, G. Di Carlo, G. Pantaleo, G. Deganello, P. L. Meo, C. Aprile, \& R. Noto, "Oxidative degradation properties of Co-based catalysts in the presence of ozone," Appl. Catal. B: Environ. vol. 75, pp. 281-289, 2007.

[29] L. Mahardiani \& Y. Kamiya, "Enhancement of Catalytic Activity of Cobalt Oxide for Catalytic Ozonation of Ammonium Ion in Water with Repeated Use," J. Jpn. Petrol. Inst., vol. 59, no. 1, pp.31-34, 2016.

[30] J. A. Moulijn, A. E. van Diepen, \& F. Kapteijn, "Catalyst deactivation: is it predictable?: What to do?," Appl. Catal. A: Gen. vol. 212, pp. 3-16, 2001.

[31] D. L. Trimm, "The regeneration or disposal of deactivated heterogeneous catalysts," Appl. Catal. A: Gen., vol. 212, pp. 153-160, 2001. 